\title{
Response of sweet corn (Zea mays L. var. saccharata) to vermicompost and inorganic fertilizer application
}

\author{
Jeffrey P. Villaver \\ Zamboanga del Sur Provincial Government College, \\ Aurora, Zamboanga del Sur, Philippines
}

\begin{abstract}
This study was conducted to determine the appropriate rate of vermicompost that would influence the agronomic performance and evaluate the effect of combining the different vermicompost rates and the specific rate of inorganic fertilizer that could effectively promote the growth and yield of sweet corn. The experiment was conducted in a Randomized Complete Block Design (RCBD) with ten (10) treatments and three (3) replications. The treatments are as follows: $\mathrm{T}_{1}-120-90-60 \mathrm{~kg} \mathrm{ha}{ }^{-1}$ inorganic fertilizer or farmers' practice, $\mathrm{T}_{2}-5 \mathrm{t} \mathrm{ha}{ }^{-1}$ vermicompost $+102-76.5-51 \mathrm{~kg} \mathrm{ha}^{-1}$ inorganic fertilizer, $\mathrm{T}_{3}-10 \mathrm{t} \mathrm{ha}^{-1}$ vermicompost $+96-72-$ $48 \mathrm{~kg} \mathrm{ha}^{-1}$ inorganic fertilizer, $\mathrm{T}_{4}-20 \mathrm{t} \mathrm{ha}^{-1}$ vermicompost $+84-63-42 \mathrm{~kg} \mathrm{ha}^{-1}$ inorganic fertilizer, $\mathrm{T}_{5}-40 \mathrm{t} \mathrm{ha}^{-1}$ vermicompost $+60-45-30 \mathrm{~kg} \mathrm{ha}^{-1}$ inorganic fertilizer, $\mathrm{T}_{6}-$ no application (control group), $\mathrm{T}_{7}-5 \mathrm{t} \mathrm{ha}^{-1}$ vermicompost, $\mathrm{T}_{8}-10 \mathrm{t} \mathrm{ha}^{-1}$ vermicompost, $\mathrm{T}_{9}-20 \mathrm{t} \mathrm{ha}{ }^{-1}$ vermicompost, and $\mathrm{T}_{10}-40 \mathrm{tha}{ }^{-1}$ vermicompost. Results of the study revealed that the different treatments influenced the ear yield (husked and unhusk), kernels per ear, weight per ear, percentage of marketable ears, percentage of barren plants, and percentage of double ears. The treatments 1 to 5 yielded significantly higher compared to the control treatment $\left(T_{6}\right)$ which implies that the application of vermicompost with $50-85 \%$ of the farmers' practice had significant improvement in sweet corn production. The application of $20 \mathrm{t} \mathrm{ha}^{-1}$ vermicompost $+70 \%$ of farmers' practice achieved the highest yield at 12.50 and $15.80 \mathrm{t} \mathrm{ha}^{-1}$ husked and unhusk ears respectively. Highest percentage of double ears at $29.69 \%$ was attained on the plants applied with $40 \mathrm{t} \mathrm{ha} \mathrm{h}^{-1}$ vermicompost + half of farmers' practice. The yields of sweet corn applied with vermicompost alone were not comparable to treatments applied with inorganic fertilizers.
\end{abstract}

Keywords: inorganic fertilizer; maize; NPK fertilizer; vermicompost; yield components

\section{Introduction}

Sweet corn (Z. mays L. var. saccharata) is one of the most favorite foods of Filipino people on all occasions for snacks because of its sweetness, juiciness, and tenderness (Srdić et al., 2011). It is sold anywhere in the Philippines along the highways, in bus or jeepney terminals, malls, or even in the local market stalls (Salazar et al., 2009). Sweet corns are rich in nutrients and vitamins (Ghosh et al., 2013), however, criticized by some health-conscious individuals due to the toxic residues resulting from inappropriate agricultural practices and intensive pesticide application (Srdić et al., 2011) and (Cutulle et al., 2018). Since it is a favorite host of Asian corn borer (ACB), farmers used chemicals extravagantly (Ozores-Hampton et al., 2013). The presence of ACB in a sweet corn plant cannot be underestimated because it would result to crop damage or eventually 
failure in crop production (Rasco Jr et al., 2008). Some experienced farmers in sweet corn production used biological control like a parasitic wasp (Trichogramma evanescens) (Gardner et al., 2011) or cultural practice like detasseling (Belfry \& Van Eerd, 2016) and (Rani et al., 2017). The use of parasitoids and detasseling are effective in controlling ACB infestation and besides, environmentally friendly (Andow, 2019). Intensive application of inorganic fertilizers is another agricultural practice that would lead to the degradation and depletion of soil fertility (Hadgu et al., 2009). Organic fertilizers can be an alternative option for inorganic fertilizers (Ayoola \& Makinde, 2009). Organically grown products command higher prices in the market (Briz \& Ward, 2009), (Aryal et al., 2009), (Akgüngör et al., 2010) and (Zander \& Hamm, 2010). Healthconscious individuals prefer to buy organically grown sweet corn, (Basha et al., 2015), (Stolz et al., 2011), (Guilabert \& Wood, 2012), and (Rana \& Paul, 2017). Farmers are aiming to produce a big and damage-free ear to attract and convince more consumers. During harvest, products are sorted into big, medium, and small. Big ears are paid higher at Php10.00 to Php15.00 by the direct buyers or consumers, while small and medium are paid at Php3.00 to Php8.00. Sweet corn is a very profitable crop to grow since it can be harvested in an ideal stage at 68 to 75 days after planting or 18 to 21 days after tasseling (Singh et al., 2010). The popularity of organic agriculture is increasing due to a continuous campaign in the awareness of climate change and biodiversity (Läpple \& Van Rensburg, 2011). If farmers abuse the usage of synthetic fertilizers and chemical pesticides, our health is at risk (Hati et al., 2008), and (Yan et al., 2013). This experiment was intentionally conducted to determine the appropriate rate of vermicompost alone and the effect of combining the different rates of vermicompost to inorganic fertilizers that would significantly boost the agronomic performance of sweet corn.

\section{Materials and Methods}

\section{Time and place of research}

The study was conducted at the crop science experimental area of the Zamboanga del Sur Provincial Government College, Aurora, Zamboanga del Sur from July to September 2019.

\section{Design}

The experiment was laid out in Randomized Complete Block Design (RCBD) with ten treatments and three replications. Details of treatments with their corresponding fertilizer rates are shown in table 1 . As shown in the table, $T_{1}$ has been applied with purely inorganic fertilizers while $T_{2}$ to $T_{5}$ was a combination of organic (vermicompost) and inorganic fertilizer at varying amount. $T_{6}$ on the other hand has zero application or no treatment at all while $T_{7}$ to $T_{10}$ were applied with organic (vermicompost) fertilizer at varying degree.

Table 1. Treatments and fertilizer rates.

\begin{tabular}{|c|c|}
\hline Treatments & Fertilizer rates \\
\hline $\mathrm{T}_{1}$ & $120 \mathrm{~kg} \mathrm{~N}-90 \mathrm{~kg} \mathrm{P}_{2} \mathrm{O}_{5}-60 \mathrm{~kg} \mathrm{~K} \mathrm{O}_{2} \mathrm{O}$ or Farmers' practice \\
\hline $\mathrm{T}_{2}$ & 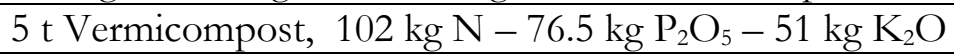 \\
\hline $\mathrm{T}_{3}$ & $10 \mathrm{t}$ Vermicompost, $96 \mathrm{~kg} \mathrm{~N}-72 \mathrm{~kg} \mathrm{P}_{2} \mathrm{O}_{5}-48 \mathrm{~kg} \mathrm{~K} \mathrm{O}_{2}$ \\
\hline $\mathrm{T}_{4}$ & $20 \mathrm{t}$ Vermicompost, $84 \mathrm{~kg} \mathrm{~N}-63 \mathrm{~kg} \mathrm{P}_{2} \mathrm{O}_{5}-42 \mathrm{~kg} \mathrm{~K} \mathrm{~K}_{2} \mathrm{O}$ \\
\hline $\mathrm{T}_{5}$ & $40 \mathrm{t}$ Vermicompost, $60 \mathrm{~kg} \mathrm{~N}-45 \mathrm{~kg} \mathrm{P}_{2} \mathrm{O}_{5}-30 \mathrm{~kg} \mathrm{~K} \mathrm{~K}_{2} \mathrm{O}$ \\
\hline $\mathrm{T}_{6}$ & Zero application or Control group \\
\hline $\mathrm{T}_{7}$ & $5 \mathrm{t}$ Vermicompost, $0 \mathrm{~kg} \mathrm{~N}-0 \mathrm{~kg} \mathrm{P}_{2} \mathrm{O}_{5}-0 \mathrm{~kg} \mathrm{~K} 2 \mathrm{O}$ \\
\hline $\mathrm{T}_{8}$ & $10 \mathrm{t}$ Vermicompost, $0 \mathrm{~kg} \mathrm{~N}-0 \mathrm{~kg} \mathrm{P}_{2} \mathrm{O}_{5}-0 \mathrm{~kg} \mathrm{~K} \mathrm{~K}_{2} \mathrm{O}$ \\
\hline $\mathrm{T}_{9}$ & $20 \mathrm{t}$ Vermicompost, $0 \mathrm{~kg} \mathrm{~N}-0 \mathrm{~kg} \mathrm{P}_{2} \mathrm{O}_{5}-0 \mathrm{~kg} \mathrm{~K} \mathrm{~K}_{2} \mathrm{O}$ \\
\hline $\mathrm{T}_{10}$ & $40 \mathrm{t}$ Vermicompost, $0 \mathrm{~kg} \mathrm{~N}-0 \mathrm{~kg} \mathrm{P}_{2} \mathrm{O}_{5}-0 \mathrm{~kg} \mathrm{~K} \mathrm{~K}_{2} \mathrm{O}$ \\
\hline
\end{tabular}




\section{Land preparation and crop establishment}

The area was plowed using a tractor for two times at one-week interval to destroy all weeds and insect pests. Furrowing was done three days after the second plowing. Vermicomposts were applied 0 DAP (basal application) while synthetic fertilizers were applied in three application times - 0 DAP, $15 \mathrm{DAP}$, and $30 \mathrm{DAP}$. Furrows were spaced at $75 \mathrm{~cm}$ apart. Two seeds were sown in each row at a depth of one $\mathrm{cm}$ and a distance of $25 \mathrm{~cm}$ between hills. Thinning was done at 12-15 DAP. Pests and diseases were monitored regularly.

\section{Harvesting}

Harvesting was done at 75 DAP. All ears were harvested in the 4 inner rows of each plot. Husked ears were sorted into small, medium, large, and non-marketable or damaged ears.

\section{Data gathered}

The plant height was measured from the ground level up to the base of the panicle at 10 days before harvesting. Ear height was measured from the ground level up the base of the primary ear. Plant height and ear height were based on the 10 randomly selected plants per plot. The weight of ears in each plot was determined using the weighing scale $(50 \mathrm{~kg}$. cap.). Weight of 10 sample ears was determined using a digital weighing scale. The diameter was obtained using a vernier caliper. The length was determined using a ruler. The number of kernels per ear was determined by counting the number of rows and multiplied by the number of kernels per row. Leaf area index was calculated using the formula below:

\section{$\mathrm{LAI}=\underline{\mathrm{L} \times \mathrm{W} \times \text { number of leaves } \times \mathrm{CF}}$ \\ PD}

Where: $\mathrm{LAI}=$ leaf area index, $\mathrm{L}=$ length, $\mathrm{W}=$ width, $\mathrm{CF}=$ correction factor of 0.75 , and $\mathrm{PD}=$ planting distance.

The yield of husked and unhusk ears in tons per hectare was calculated using the formula:

$$
\text { Yield }\left(\mathrm{t} \mathrm{ha}^{-1}\right)=\frac{\text { plot weight }(\mathrm{kg})}{\text { Plot size }(\mathrm{sq} . \mathrm{m} .)} \frac{10,000(\mathrm{sq} . \mathrm{m} / \mathrm{ha})}{1,000(\mathrm{~kg} / \mathrm{t})}
$$

\section{Statistical Tools}

The study used descriptive statistics specifically percentage in determining the marketable ears, barren plants, and double ears. An F-test or Analysis of Variance (ANOVA) was used to determine the response or influence of organic (vermicompost) and inorganic fertilizer to the sweet corn plant. Tukey's test or honestly significant difference (HSD) test was used to compare the treatment differences. Moreover, the principal component analysis was used to determine the relationships of yield to other yield components.

\section{Results and Discussion}

\section{Plant height and ear height $(\mathrm{cm})$}

The plant height and ear height is presented in table 2. The tallest plant height and ear height were obtained in $\mathrm{T}_{5}\left(40 \mathrm{t} \mathrm{ha}^{-1} \mathrm{VC}, 60-45-30 \mathrm{NPK} \mathrm{kg} \mathrm{ha}{ }^{-1}\right)$ at 198 and $67.06 \mathrm{~cm}$ respectively. Statistical analysis did not reveal any significant difference in the plant height and ear height of sweet corn as influenced by vermicompost and inorganic fertilizer application. The study of (Joshi et al., 2015) revealed that vermicompost improved the plants' height due to humic acid and growth promoting bacteria. Khan Mohammadi et al.(2017) found out that vermicompost with the combination of inorganic fertilizers at various levels enhanced the plant height and ear 
height of sweet corn. Thus, in this study, it is obvious that the highest rate of vermicompost at $40 \mathrm{t} \mathrm{ha}^{-1}$ with inorganic fertilizer produced the highest plant height and ear height, although statistically insignificant.

Table 2. Plant height and ear height of sweet corn.

\begin{tabular}{|c|c|c|}
\hline Treatments & $\begin{array}{c}\text { Plant height }(\mathrm{cm}) \\
\pm S E\end{array}$ & $\begin{array}{c}\text { Ear height }(\mathrm{cm}) \\
\pm \mathrm{SE}\end{array}$ \\
\hline $\mathrm{T}_{1}-120-90-60 \mathrm{NPK}\left(\mathrm{kg} \mathrm{ha}^{-1}\right)$ or Farmers' Practice & $177.67 \pm 10.3$ & $58.00 \pm 6.53$ \\
\hline $\mathrm{T}_{2}-5 \mathrm{t} \mathrm{ha}^{-1} \mathrm{VC} ; 102-76.5-51 \mathrm{NPK}\left(\mathrm{kg} \mathrm{ha}^{-1}\right)$ & $172.00 \pm 2.78$ & $53.83 \pm 6.39$ \\
\hline $\mathrm{T}_{3}-10 \mathrm{t} \mathrm{ha}^{-1} \mathrm{VC} ; 96-72-48 \mathrm{NPK}\left(\mathrm{kg} \mathrm{ha}^{-1}\right)$ & $180.77 \pm 3.62$ & $66.17 \pm 1.20$ \\
\hline $\mathrm{T}_{4}-20 \mathrm{tha}^{-1} \mathrm{VC} ; 84-63-42 \mathrm{NPK}\left(\mathrm{kg} \mathrm{ha}^{-1}\right)$ & $177.33 \pm 3.44$ & $67.00 \pm 0.29$ \\
\hline $\mathrm{T}_{5}-40 \mathrm{t} \mathrm{ha}^{-1} \mathrm{VC} ; 60-45-30 \mathrm{NPK}\left(\mathrm{kg} \mathrm{ha}^{-1}\right)$ & $198.00 \pm 10.2$ & $67.06 \pm 3.22$ \\
\hline $\mathrm{T}_{6}-$ Zero Application (Control) & $161.50 \pm 2.57$ & $53.00 \pm 3.04$ \\
\hline $\mathrm{T}_{7}-5 \mathrm{t} \mathrm{ha}^{-1} \mathrm{VC} ; 0-0-0 \mathrm{NPK}\left(\mathrm{kg} \mathrm{ha}^{-1}\right)$ & $168.50 \pm 5.77$ & $55.50 \pm 3.33$ \\
\hline $\mathrm{T}_{8}-10 \mathrm{t} \mathrm{ha}^{-1}$ VC0-0-0 NPK $\left(\mathrm{kg} \mathrm{ha}^{-1}\right)$ & $161.50 \pm 10.5$ & $62.83 \pm 1.64$ \\
\hline $\mathrm{T}_{9}-20 \mathrm{t} \mathrm{ha}^{-1} \mathrm{VC} ; 0-0-0 \mathrm{NPK}\left(\mathrm{kg} \mathrm{ha}^{-1}\right)$ & $168.67 \pm 2.89$ & $59.17 \pm 4.48$ \\
\hline $\mathrm{T}_{10}-40 \mathrm{t} \mathrm{ha}^{-1} \mathrm{VC} ; 0-0-0 \mathrm{NPK}\left(\mathrm{kg} \mathrm{h}^{-1}\right)$ & $172.17 \pm 8.12$ & $48.17 \pm 9.06$ \\
\hline F-test & ns & ns \\
\hline C.V. (\%) & 8.75 & 14.01 \\
\hline
\end{tabular}

ns-non-significant

\section{Leaf area index (LAI)}

Table 3 shows the LAI of sweet corn at 65 DAP. Treatment 3 obtained the highest LAI at 3.66 followed by $\mathrm{T}_{4}$ at 3.64. Results revealed no significant difference in the LAI of sweet corn at 65 DAP as affected by vermicompost and inorganic fertilizers. The experiment conducted by (Bekele et al., 2018) proved the efficacy of combining vermicompost with the inorganic fertilizer to improve the leaf area index in corn. The study of (Rasool et al., 2015)about combining inorganic and organic fertilizer improved the leaf area index of sweet corn. The result confirmed the findings of (Fahrurrozi et al., 2017) where, they found out that the organic foliar fertilizer did not reveal significant result on the leaf area of sweet corn. The leaf area index data are not significant; however, it clearly shows the pattern of increase when applied with the combination of vermicompost and inorganic fertilizer compared to the control group.

Table 3. Leaf area index of sweet corn as influenced by vermicompost and inorganic fertilizer application in Aurora, Zamboanga del Sur.

\begin{tabular}{|l|c|}
\hline \multicolumn{1}{|c|}{ Treatments } & Leaf area index \\
\hline $\mathrm{T}_{1}-120-90-60 \mathrm{NPK}\left(\mathrm{kg} \mathrm{ha}^{-1}\right)$ or Farmers' Practice & 3.07 \\
\hline $\mathrm{T}_{2}-5 \mathrm{t} \mathrm{ha}^{-1} \mathrm{VC} ; 102-76.5-51 \mathrm{NPK}\left(\mathrm{kg} \mathrm{ha}^{-1}\right)$ & 3.18 \\
\hline $\mathrm{T}_{3}-10 \mathrm{t} \mathrm{ha}^{-1} \mathrm{VC} ; 96-72-48 \mathrm{NPK}\left(\mathrm{kg} \mathrm{ha}^{-1}\right)$ & 3.66 \\
\hline $\mathrm{T}_{4}-20 \mathrm{t} \mathrm{ha}^{-1} \mathrm{VC} ; 84-63-42 \mathrm{NPK}\left(\mathrm{kg} \mathrm{ha}^{-1}\right)$ & 3.64 \\
\hline $\mathrm{T}_{5}-40 \mathrm{t} \mathrm{ha}^{-1} \mathrm{VC} ; 60-45-30 \mathrm{NPK}\left(\mathrm{kg} \mathrm{ha}^{-1}\right)$ & 3.51 \\
\hline $\mathrm{T}_{6}-\mathrm{Zero} \mathrm{Application}(\mathrm{Control})^{-1} \mathrm{~T}_{7}-5 \mathrm{t} \mathrm{ha}^{-1} \mathrm{VC} ; 0-0-0 \mathrm{NPK}\left(\mathrm{kg} \mathrm{ha}^{-1}\right)$ & 2.72 \\
\hline $\mathrm{T}_{8}-10 \mathrm{t} \mathrm{ha}^{-1} \mathrm{VC} 0-0-0 \mathrm{NPK}\left(\mathrm{kg} \mathrm{ha}^{-1}\right)$ & 2.46 \\
\hline $\mathrm{T}_{9}-20 \mathrm{t} \mathrm{ha}^{-1} \mathrm{VC} ; 0-0-0 \mathrm{NPK}\left(\mathrm{kg} \mathrm{ha}^{-1}\right)$ & 3.16 \\
\hline $\mathrm{T}_{10}-40 \mathrm{t} \mathrm{ha}^{-1} \mathrm{VC} ; 0-0-0 \mathrm{NPK}\left(\mathrm{kg} \mathrm{ha}^{-1}\right)$ & 3.05 \\
\hline F-test & 3.33 \\
\hline C.V. $\%$ (\%) & $\mathrm{ns}$ \\
\hline ns - non-significant & 8.75 \\
\hline
\end{tabular}




\section{Yield of husked and unhusk ears $\left(\mathrm{t} \mathrm{ha}^{-1}\right)$}

The yields of husked and unhusk ears are shown in figure 1. The data show that the yields in treatments from 1 to 5 differed significantly from the rests of treatments which means that the application of vermicompost in combination with the FP at $50-85 \%$ had significant improvement in crop production. The rate of $20 \mathrm{t} \mathrm{ha}^{-1}$ of vermicompost with $60 \%$ of the FP attained the highest yield at 12.50 and $15.81 \mathrm{t} \mathrm{ha}^{-1}$ in husked and unhusked ears respectively. The yields of sweet corn applied with vermicompost alone were significantly lower compared to vermicompost with inorganic fertilizer application. The result also suggests that the nutrients present in the vermicompost are released slowly, thus they are not comparable to treatments with inorganic fertilizers (Densilin et al., 2011). The study of (Canatoy, 2018) mentioned that the recommended rate of inorganic fertilizer +1 ton of vermicompost produced the highest ear yield. The application of compost and inorganic fertilizers improved the yield of corn and at the same time improve the soil organic carbon (Zhang et al., 2016).

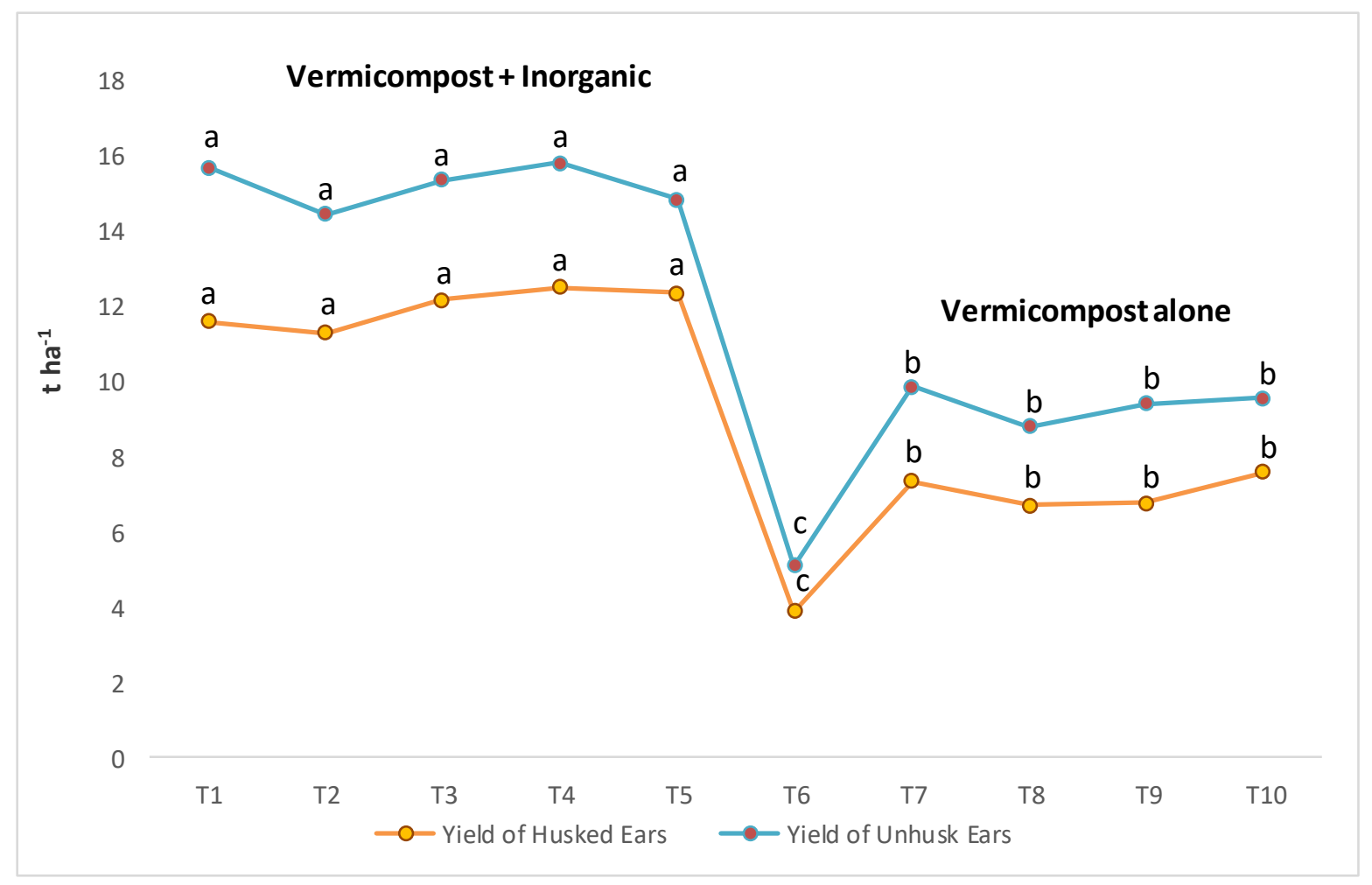

Figure 1. Yield of husked and unhusk ears of sweet corn in response to vermicompost and inorganic fertilizer application in Aurora, Zamboanga del Sur.

\section{Percentage of marketable ears, barren plants, and double ears}

Percentage of marketable ears, barren plants, and double ears are shown in table 4. As shown, $\mathrm{T}_{4}$ got the highest percentage of marketable ears as revealed by $93.91 \%$ while $\mathrm{T}_{6}$ obtained the least at $52.99 \%$. The highest percentage of barren plants was attained in $\mathrm{T}_{6}$ at $29.17 \%$. Highest percentage of double ears was significantly higher in $\mathrm{T}_{4}$. Pests and diseases greatly affected the percentage of marketable ears. Asian corn borer, corn earworm, and fall armyworms are the most damaging pests in corn (Lima et al., 2010). Reduction of sizes and grain filling due to weed competition (Silva et al., 2010) also influenced the percentage of marketable ears. Sufficient application of fertilizers such as nitrogen, phosphorus, and potassium improved the sizes, grain filling and double ears (Ma et al., 2012) and (Silva et al., 2013). Insufficient supply of fertilizers increased the percentage of barren plants (Kumar et al., 2015). 
Table 4. Percentage of marketable ears, barren plants and double ears.

\begin{tabular}{|l|c|c|c|}
\hline \multicolumn{1}{|c|}{ Treatments } & $\begin{array}{c}\text { Marketable ears } \\
(\%)\end{array}$ & $\begin{array}{c}\text { Barren plants } \\
(\%)\end{array}$ & $\begin{array}{c}\text { Double ears } \\
(\%)\end{array}$ \\
\hline $\mathrm{T}_{1}-0 \mathrm{t} \mathrm{ha}^{-1} \mathrm{VC} ; 120-90-60 \mathrm{NPK}\left(\mathrm{kg} \mathrm{ha}^{-1}\right)$ & $84.53^{\mathrm{ab}}$ & $0.00^{\mathrm{b}}$ & $18.75^{\mathrm{ab}}$ \\
\hline $\mathrm{T}_{2}-5 \mathrm{t} \mathrm{ha}^{-1} \mathrm{VC} ; 102-76.5-51 \mathrm{NPK}\left(\mathrm{kg} \mathrm{ha}^{-1}\right)$ & $84.86^{\mathrm{ab}}$ & $0.00^{\mathrm{b}}$ & $17.19^{\mathrm{ab}}$ \\
\hline $\mathrm{T}_{3}-10 \mathrm{t} \mathrm{ha}^{-1} \mathrm{VC} ; 96-72-48 \mathrm{NPK}\left(\mathrm{kg} \mathrm{h}^{-1}\right)$ & $88.58^{\mathrm{ab}}$ & $0.00^{\mathrm{b}}$ & $18.23^{\mathrm{ab}}$ \\
\hline $\mathrm{T}_{4}-20 \mathrm{t} \mathrm{ha}^{-1} \mathrm{VC} ; 84-63-42 \mathrm{NPK}\left(\mathrm{kg} \mathrm{ha}^{-1}\right)$ & $93.91^{\mathrm{a}}$ & $0.52^{\mathrm{b}}$ & $7.29^{\mathrm{b}}$ \\
\hline $\mathrm{T}_{5}-40 \mathrm{t} \mathrm{ha}^{-1} \mathrm{VC} ; 60-45-30 \mathrm{NPK}\left(\mathrm{kg} \mathrm{ha}^{-1}\right)$ & $80.70^{\mathrm{abc}}$ & $0.00^{\mathrm{b}}$ & $29.69^{\mathrm{a}}$ \\
\hline $\mathrm{T}_{6}-0 \mathrm{t} \mathrm{ha}^{-1} \mathrm{VC} ; 0-0-0 \mathrm{NPK}\left(\mathrm{kg} \mathrm{ha}^{-1}\right)$ & $52.99^{\mathrm{d}}$ & $29.17^{\mathrm{a}}$ & $0.00^{\mathrm{b}}$ \\
\hline $\mathrm{T}_{7}-5 \mathrm{t} \mathrm{ha}^{-1} \mathrm{VC} ; 0-0-0 \mathrm{NPK}\left(\mathrm{kg} \mathrm{ha}^{-1}\right)$ & $70.26^{\mathrm{bcd}}$ & $0.52^{\mathrm{b}}$ & $6.77^{\mathrm{b}}$ \\
\hline $\mathrm{T}_{8}-10 \mathrm{t} \mathrm{ha}^{-1} \mathrm{VC} 0-0-0 \mathrm{NPK}\left(\mathrm{kg} \mathrm{ha}^{-1}\right)$ & $61.75^{\mathrm{cd}}$ & $0.00^{\mathrm{b}}$ & $6.77^{\mathrm{b}}$ \\
\hline $\mathrm{T}_{9}-20 \mathrm{t} \mathrm{ha}^{-1} \mathrm{VC} ; 0-0-0 \mathrm{NPK}\left(\mathrm{kg} \mathrm{ha}^{-1}\right)$ & $61.84^{\mathrm{cd}}$ & $0.00^{\mathrm{b}}$ & $15.10^{\mathrm{ab}}$ \\
\hline $\mathrm{T}_{10}-40 \mathrm{t} \mathrm{ha}^{-1} \mathrm{VC} ; 0-0-0 \mathrm{NPK}\left(\mathrm{kg} \mathrm{ha}^{-1}\right)$ & $70.24^{\mathrm{bcd}}$ & $0.00^{\mathrm{b}}$ & $7.29^{\mathrm{b}}$ \\
\hline F-test & $* *$ & $* *$ & $* *$ \\
\hline C.V. $\%)$ & 9.54 & 32.00 & 53.20 \\
\hline
\end{tabular}

**-significant at 1\% level of Tukey's pairwise comparisons

\section{Yield components of sweet corn}

The yield components of sweet corn are presented in table 5. Statistical analysis reveal any significant difference in all treatments in terms of the the kernels per ear and weight per ear. Treatment 4 achieved the highest number of kernels per ear at 670. Treatments 3 and 4 got the heaviest weight per ear at 313.33 and $305 \mathrm{~g}$ respectively. Increased in the number of rows, kernels per ear, and weight per ear are influenced by NPK fertilization (Mukhtar et al., 2011) and (Baral et al., 2016). The results of the study was similar to the findings of (Marlina et al., 2017), (Pangaribuan \& Hendarto, 2018), and (Sofyan et al., 2019) in which the yield components are increased with the application of inorganic and organic fertilizers at the highest rates of 10 to $20 \mathrm{t}$ $\mathrm{ha}^{-1}$.

Table 5. Yield components of sweet corn as influenced by vermicompost and inorganic fertilizer application.

\begin{tabular}{|l|c|c|c|c|c|}
\hline \multicolumn{1}{|c|}{ Treatments } & $\begin{array}{c}\text { Diameter } \\
(\mathrm{cm})\end{array}$ & $\begin{array}{c}\text { Length } \\
(\mathrm{cm})\end{array}$ & $\begin{array}{c}\text { Number } \\
\text { of rows }\end{array}$ & $\begin{array}{c}\text { Kernels } \\
\text { per ear }\end{array}$ & $\begin{array}{c}\text { Weight } \\
\text { per ear }(\mathrm{g})\end{array}$ \\
\hline $\mathrm{T}_{1}-120-90-60 \mathrm{NPK}\left(\mathrm{kg} \mathrm{ha}^{-1}\right)$ & 4.92 & 17.69 & 16 & $584^{\mathrm{ab}}$ & $270.00^{\mathrm{ab}}$ \\
\hline $\mathrm{T}_{2}-5 \mathrm{t} \mathrm{ha}^{-1} \mathrm{VC} ; 102-76.5-51 \mathrm{NPK}\left(\mathrm{kg} \mathrm{ha}^{-1}\right)$ & 4.88 & 16.42 & 16 & $603^{\mathrm{ab}}$ & $273.33^{\mathrm{ab}}$ \\
\hline $\mathrm{T}_{3}-10 \mathrm{t} \mathrm{ha}^{-1} \mathrm{VC} ; 96-72-48 \mathrm{NPK}\left(\mathrm{kg} \mathrm{ha}^{-1}\right)$ & 4.80 & 17.26 & 16 & $617 \mathrm{ab}^{\mathrm{ab}}$ & $313.33^{\mathrm{a}}$ \\
\hline $\mathrm{T}_{4}-20 \mathrm{t} \mathrm{ha}^{-1} \mathrm{VC} ; 84-63-42 \mathrm{NPK}\left(\mathrm{kg} \mathrm{ha}^{-1}\right)$ & 4.88 & 18.56 & 17 & $670^{\mathrm{a}}$ & $305.00^{\mathrm{a}}$ \\
\hline $\mathrm{T}_{5}-40 \mathrm{t} \mathrm{ha}^{-1} \mathrm{VC} ; 60-45-30 \mathrm{NPK}\left(\mathrm{kg} \mathrm{ha}^{-1}\right)$ & 4.77 & 17.64 & 17 & $606^{\mathrm{ab}}$ & $256.67 \mathrm{abc}$ \\
\hline $\mathrm{T}_{6}-\mathrm{Control} \mathrm{group}$ & 4.57 & 14.34 & 16 & $471^{\mathrm{b}}$ & $183.33^{\mathrm{c}}$ \\
\hline $\mathrm{T}_{7}-5 \mathrm{t} \mathrm{ha}^{-1} \mathrm{VC} ; 0-0-0 \mathrm{NPK}\left(\mathrm{kg} \mathrm{ha}^{-1}\right)$ & 4.59 & 16.13 & 15 & $522^{\mathrm{ab}}$ & $225.00^{\mathrm{bc}}$ \\
\hline $\mathrm{T}_{8}-10 \mathrm{t} \mathrm{ha}^{-1} \mathrm{VC}-0-0 \mathrm{NPK}\left(\mathrm{kg} \mathrm{ha}^{-1}\right)$ & 4.80 & 15.03 & 16 & $474^{\mathrm{b}}$ & $215.00^{\mathrm{bc}}$ \\
\hline $\mathrm{T}_{9}-20 \mathrm{t} \mathrm{ha}^{-1} \mathrm{VC} ; 0-0-0 \mathrm{NPK}\left(\mathrm{kg} \mathrm{ha}^{-1}\right)$ & 4.58 & 15.37 & 16 & $526^{\mathrm{ab}}$ & $221.677^{\mathrm{bc}}$ \\
\hline $\mathrm{T}_{10}-40 \mathrm{tha}^{-1} \mathrm{VC} ; 0-0-0 \mathrm{NPK}\left(\mathrm{kg} \mathrm{ha}^{-1}\right)$ & 4.50 & 15.66 & 16 & $534^{\mathrm{ab}}$ & $236.67 \mathrm{abc}$ \\
\hline Test of significance & $\mathrm{ns}$ & $\mathrm{ns}$ & $\mathrm{ns}$ & $* *$ & $* *$ \\
\hline C.V. $(\%)$ & 4.87 & 10.24 & 4.50 & 9.10 & 10.76 \\
\hline
\end{tabular}

ns-non significant

**-significant at 1\% level of Tukey's pairwise comparisons 


\section{Principal component analysis of yield and yield components of sweet corn}

\section{Scree plot}

The scree plot of yield and yield components of sweet corn as influenced by vermicompost and inorganic application is presented in figure 2. As shown, the first principal component (PC) accounts for most of the total variability in the data as reflected in the eigenvalues. The remaining PCs account for a smaller portion of variability which is smaller than one and is not important. As mentioned by Hair et al., (1998) and (Shegro et al., 2013), the components attained an eigenvalue less than 1 should be eliminated and the eigenvalues greater than 1 with component loadings greater than \pm 0.3 are considered significant.

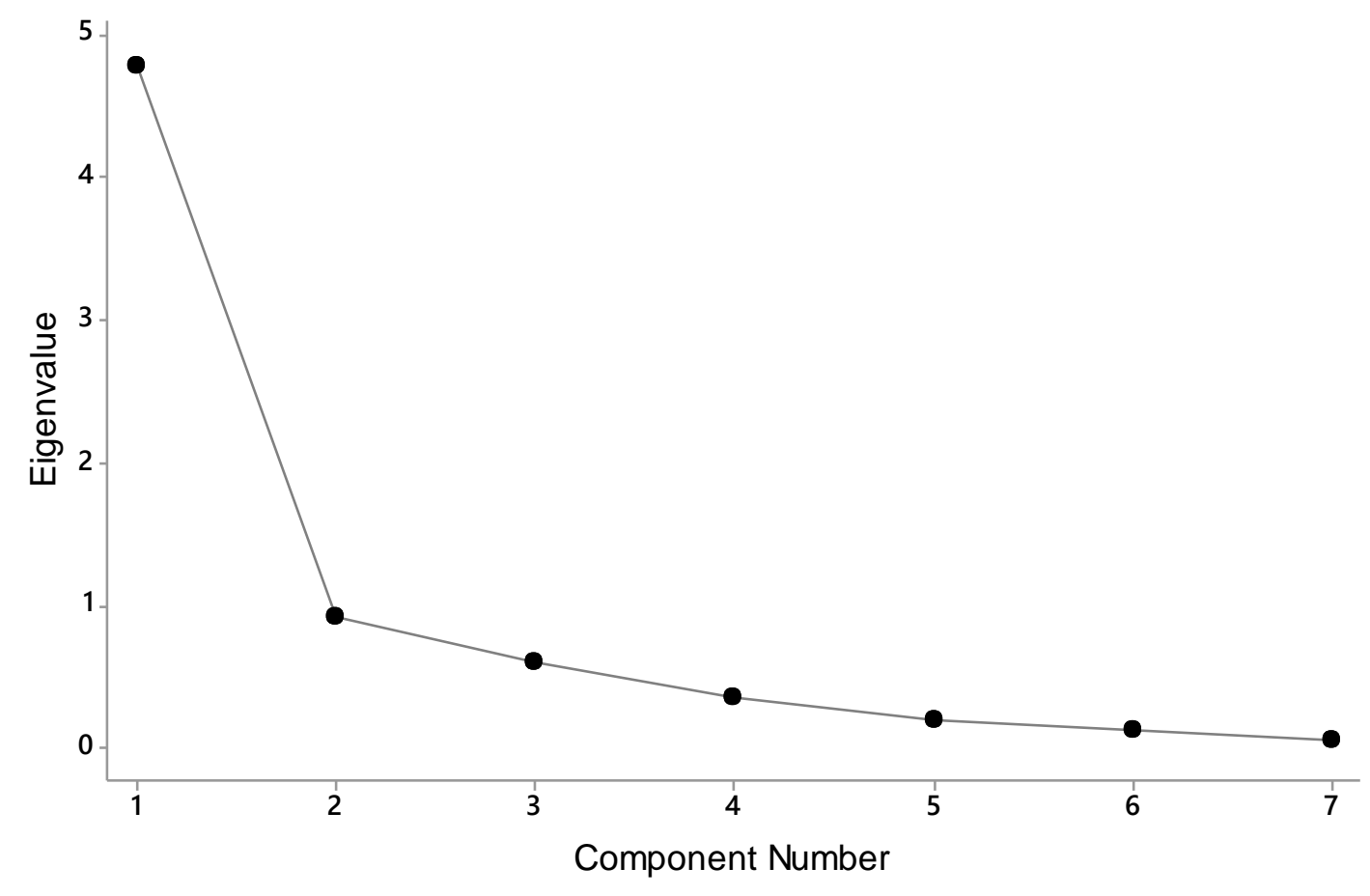

Figure 2. Scree plot of yield and yield components of sweet corn.

\section{Principal component analysis}

The principal component analysis of yield and yield components of sweet corn is presented in table 6. The first principal component has an eigenvalue greater than 1 represents $68 \%$ of the total variability suggesting that the first PC adequately explains the variation of the study. For the data on yield (0.420), weight per ear (0.411), percentage of marketable ears (0.414), kernels per ear (0.432), and length (0.351) had the highest positive loadings on component 1 . Results suggest that the yield is increased when the weight per ear, percentage of marketable ears, kernels per ear, and length also increased (Yazdani et al., 2009), (Maske et al., 2018) and (Villaver, 2019). Increasing its size can be attained through proper fertilizer application (Asghar et al., 2010). Increased percentage of marketable ears can be achieved with proper cultural practices to attain damage-free ears (Cruz et al., 2015). An increase in length and kernels per ear is influenced by sufficient application of potassium (Anser Ali \& Hussain, 2012). 
Table 6. Principal component analysis of yield and yield components of sweet corn in response to vermicompost and inorganic fertilizer application.

\begin{tabular}{|c|c|c|c|c|c|}
\hline & \multicolumn{5}{|c|}{ Component Loadings } \\
\hline Variables & PC1 & PC2 & PC3 & PC4 & PC5 \\
\hline Yield $\left(\mathrm{t} \mathrm{ha}^{-1}\right)$ & $\underline{0.420}$ & 0.133 & -0.130 & 0.362 & 0.232 \\
\hline Weight per ear $(\mathrm{g})$ & $\underline{0.411}$ & 0.243 & -0.084 & 0.206 & -0.783 \\
\hline$\%$ of marketable ears & 0.414 & 0.146 & 0.022 & 0.447 & 0.494 \\
\hline Diameter & $\overline{0.293}$ & -0.392 & 0.866 & -0.006 & -0.070 \\
\hline Length & 0.351 & 0.480 & 0.106 & -0.724 & 0.224 \\
\hline Number of rows & 0.295 & -0.705 & -0.416 & -0.208 & 0.099 \\
\hline \multirow{2}{*}{ Kernels per ear } & $\underline{0.432}$ & -0.144 & -0.204 & -0.244 & -0.157 \\
\hline & \multicolumn{5}{|c|}{ Eigenanalysis of the Correlation Matrix } \\
\hline Eigenvalue & 4.775 & 0.913 & 0.599 & 0.350 & 0.187 \\
\hline Proportion & 0.682 & 0.130 & 0.086 & 0.050 & 0.027 \\
\hline Cumulative & 0.682 & 0.812 & 0.898 & 0.948 & 0.095 \\
\hline
\end{tabular}

\section{Conclusion}

The application of vermicompost and inorganic fertilizers did not influence on the plant height, ear height, leaf area index, diameter, length, and the number of rows. However, a significant increase in the yield of husked and unhusk ears was observed when applied with vermicompost and inorganic fertilizers. The yield of sweet corn applied with pure vermicompost is not comparable to inorganic fertilizers. The percentage of marketable ears and kernels per ear were significantly higher when applied with $70 \%$ of farmers' practice and $20 \mathrm{t} \mathrm{ha}^{-1}$ vermicompost. Highest percentage of double ears was achieved by the plants applied with $50 \%$ of farmers' practice and $40 \mathrm{t} \mathrm{ha}^{-1}$ vermicompost. Highest weight per ear was achieved in $\mathrm{T}_{3}$ and $\mathrm{T}_{4}$ with 313.13 and $305.00 \mathrm{~g}$ respectively. Control treatment (no fertilization) obtained the highest percentage of barren plants. The yield of sweet corn greatly affected with the increasing weight per ear, length, kernels per ear, and percentage of marketable ears. The results of this study show the effect of using pure vermicompost at the optimum rate which is incomparable to vermicompost with the farmer's practice. This would provide valuable information to the farmers who want to engage in sweet corn production using vermicompost and inorganic fertilizer. Further study is recommended to include parameters like fertility of the soil, water holding capacity, and bulk density after the experiment conducted.

\section{References}

Akgüngör, S., Miran, B., \& Abay, C. (2010). Consumer willingness to pay for organic food in urban Turkey. Journal of International Food \& Agribusiness Marketing, 22(3-4), 299-313.

Andow, D. A. (2019). Corn IPM and Trichogramma. Ecological Interactions And Biological Control.

Anser Ali, M., \& Hussain, S. (2012). Nutritional and physiological significance of potassium application in maize hybrid crop production. Pak J Nutri, 11(2), 187-202.

Aryal, K. P., Chaudhary, P., Pandit, S., \& Sharma, G. (2009). Consumers' willingness to pay for organic products: A case from Kathmandu valley. Journal of Agriculture and Environment, 10, 15-26.

Asghar, A., Ali, A., Syed, W. H., Asif, M., Khaliq, T., \& Abid, A. A. (2010). Growth and yield of maize (Zea mays L.) cultivars affected by NPK application in different proportion. Pakistan Journal of Science, 62(4), 211-216.

Ayoola, O. T., \& Makinde, E. (2009). Maize growth, yield and soil nutrient changes with $\mathrm{N}$-enriched organic fertilizers. African Journal of Food, Agriculture, Nutrition and Development, 9(1), 580-592. 
Baral, B. R., Adhikari, P., \& Shrestha, J. (2016). Productivity and Economics of Hybrid Maize (Zea mays L.) under different Fertilizer Doses in the Inner Terai Region of Nepal. Journal of AgriSearch, 3(1), $13-16$.

Basha, M. B., Mason, C., Shamsudin, M. F., Hussain, H. I., \& Salem, M. A. (2015). Consumers attitude towards organic food. Procedia Economics and Finance, 31, 444-452.

Bekele, A., Kibret, K., Bedadi, B., Balemi, T., \& Yli-Halla, M. (2018). Effects of lime, vermicompost and chemical P fertilizer on yield of maize in Ebantu District, Western highlands of Ethiopia. African Journal of Agricultural Research, 13(10), 477-489.

Belfry, K. D., \& Van Eerd, L. L. (2016). Establishment and impact of cover crops intersown into corn. Crop Science, 56(3), 1245-1256.

Briz, T., \& Ward, R. W. (2009). Consumer awareness of organic products in Spain: An application of multinominal logit models. Food Policy, 34(3), 295-304.

Canatoy, R. C. (2018). Effects of vermicompost on the growth and yield of sweet corn in Bukidnon, Philippines. Asian Journal of Soil Science and Plant Nutrition, 1-8.

Cruz, C. A., Meneses, N. B., da Cunha, T. P. L., Nowaki, R. H. D., \& Barbosa, J. C. (2015). Influence of amount and parceling of nitrogen fertilizer on productivity and industrial revenue of sweet corn ("Zea mays" L.). Australian Journal of Crop Science, 9(10), 895.

Cutulle, M. A., Armel, G. R., Kopsell, D. A., Wilson, H. P., Brosnan, J. T., Vargas, J. J., Hines, T. E., \& Koepke-Hill, R. M. (2018). Several pesticides influence the nutritional content of sweet corn. Journal of Agricultural and Food Chemistry, 66(12), 3086-3092.

Densilin, D. M., Srinivasan, S., Manju, P., \& Sudha, S. (2011). Effect of individual and combined application of biofertilizers, inorganic fertilizer and vermicompost on the biochemical constituents of chilli (Ns-1701). J Biofertil Biopestici, 2(106), 2.

Fahrurrozi, F., Muktamar, Z., Dwatmadji, D., Setyowati, N., Sudjatmiko, S., \& Chozin, M. (2017). Growth and yield responses of three sweet corn (Zea mays L. var. Saccharata) varieties to local-based liquid organic fertilizer.

Gardner, J., Hoffmann, M. P., Pitcher, S. A., \& Harper, J. K. (2011). Integrating insecticides and Trichogramma ostriniae to control European corn borer in sweet corn: Economic analysis. Biological Control, 56(1), 9-16.

Ghosh, B. C., Bera, N., Das, D., \& Swain, D. K. (2013). Effect of varying soil and vermicompost mixtures on growing media and yield and quality of sweet corn. International Conference on Food and Agricultural Sciences, 55, 38-42.

Guilabert, M., \& Wood, J. A. (2012). USDA certification of food as organic: An investigation of consumer beliefs about the health benefits of organic food. Journal of Food Products Marketing, 18(5), 353-368.

Hadgu, K. M., Rossing, W. A., Kooistra, L., \& van Bruggen, A. H. (2009). Spatial variation in biodiversity, soil degradation and productivity in agricultural landscapes in the highlands of Tigray, northern Ethiopia. Food Security, 1(1), 83-97.

Hair, J. F., Black, W. C., Babin, B. J., Anderson, R. E., \& Tatham, R. L. (1998). Multivariate data analysis (Vol. 5). Prentice hall Upper Saddle River, NJ.

Hati, K. M., Swarup, A., Mishra, B., Manna, M. C., Wanjari, R. H., Mandal, K. G., \& Misra, A. K. (2008). Impact of long-term application of fertilizer, manure and lime under intensive cropping on physical properties and organic carbon content of an Alfisol. Geoderma, 148(2), 173-179.

Joshi, R., Singh, J., \& Vig, A. P. (2015). Vermicompost as an effective organic fertilizer and biocontrol agent: Effect on growth, yield and quality of plants. Reviews in Environmental Science and Bio/Technology, 14(1), 137-159.

khan Mohammadi, N., Pankhaniya, R. M., Patel, K. M., \& Rahmani, N. (2017). Effect of various levels of inorganic fertilizer and vermicompost with and without bio-fertilizer on growth, yield attributes and yield of sweet corn (Zea mays L. saccharata).

Kumar, R., Bohra, J. S., Singh, A. K., \& Kumawat, N. (2015). Productivity, profitability and nutrient-use efficiency of baby corn (Zea mays) as influenced of varying fertility levels. Indian Journal of Agronomy, 60(2), 285-290. 
Läpple, D., \& Van Rensburg, T. (2011). Adoption of organic farming: Are there differences between early and late adoption? Ecological Economics, 70(7), 1406-1414.

Lima, M. S., Silva, P. S. L., Oliveira, O. F., Silva, K. M. B., \& Freitas, F. C. L. (2010). Corn yield response to weed and fall armyworm controls. Planta Daninha, 28(1), 103-111.

Ma, R. X., Wang, J. S., Li, X. Z., \& Liu, W. C. (2012). Effect of different npk fertilizers cooperating application on yield and quality of high starch maize. Applied Mechanics and Materials, 214, 423429.

Marlina, N., Amir, N., Aminah, R. I. S., Nasser, G. A., Purwanti, Y., \& Nisfuriah, L. (2017). Organic and Inorganic Fertilizers Application on NPK Uptake and Production of Sweet Corn in Inceptisol Soil of Lowland Swamp Area. MATEC Web of Conferences, 97, 01106.

Maske, N. M., Pramanik, K., \& Asewar, B. V. (2018). Correlation studies for yield and yield contributing characters in sweetcorn (Zea mays L. saccharata). Int. J. Bio-Res. Env. Agril. Sci.

Mukhtar, T., Arif, M., Hussain, S., Tariq, M., \& Mehmood, K. (2011). Effect of different rates of nitrogen and phosphorus fertilizers on growth and yield of maize. J. Agric. Res, 49(3), 333-339.

Ozores-Hampton, M., McAvoy, E. J., Dittmar, P. J., Webb, S. E., Raid, R. N., \& Olson, S. M. (2013). Sweet corn production. University of Florida Institute of Food and Agricultural Sciences, HS, 737.

Pangaribuan, D. H., \& Hendarto, K. (2018). The effect of organic fertilizer and urea fertilizer on growth, yield and quality of sweet corn and soil health. Asian Journal of Agriculture and Biology, 6(3), 335344.

Rana, J., \& Paul, J. (2017). Consumer behavior and purchase intention for organic food: A review and research agenda. Journal of Retailing and Consumer Services, 38, 157-165.

Rani, R., Sheoran, R. K., Soni, P. G., Kaith, S., \& Sharma, A. (2017). Baby corn: A wonderful vegetable. International Journal of Science, Environment and Technology, 6(2), 1407-1412.

Rasco Jr, E. T., Mangubat, J. R., Burgonio, A. B., Logrono, M. L., Villegas, V. N., \& Fernandez, E. C. (2008). Efficacy of insect-protected maize (Bt-11) against asiatic corn borer (Ostrinia furnacalis Guenee). Philippine Journal of Crop Science, 33(3), 82-89.

Rasool, S., Kanth, R. H., Hamid, S., Raja, W., Alie, B. A., \& Dar, Z. A. (2015). Influence of Integrated nutrient management on growth and yield of sweet corn (Zea mays L. Saccharata) under temperate conditions of Kashmir valley. Journal of Experimental Agriculture International, 315-325.

Salazar, A. M., Manguiat, P. H., Laude, T. P., \& Beltran, A. K. M. (2009). Breeding of special maize types: Sweet corn. Philippine Journal of Crop Science (Philippines).

Shegro, A., Labuschagne, M. T., Shargie, N. G., \& van Biljon, A. (2013). Multivariate Analysis of Nutritional Diversity in Sorghum Landrace Accessions from Western Ethiopia.

Silva, P. S. L., Silva, K. M. B., Silva, P. I. B., Oliveira, V. R., \& Ferreira, J. L. B. (2010). Green ear yield and grain yield of maize cultivars in competition with weeds. Planta Daninha, 28(1), 77-85.

Silva, Paulo Sérgio L., Araújo Júnior, B. B., Oliveira, V. R., Pontes, F. S., \& Oliveira, O. F. (2013). Effects of nitrogen application on corn yield after harvesting the apical ear as baby corn. Horticultura Brasileira, 31(3), 419-425.

Singh, M. K., Singh, R. N., Singh, S. P., Yadav, M. K., \& Singh, V. K. (2010). Integrated nutrient management for higher yield, quality and profitability of baby corn (Zea mays). Indian Journal of Agronomy, 55(2), 100.

Sofyan, E. T., Sara, D. S., \& Machfud, Y. (2019). The effect of organic and inorganic fertilizer applications on N, P-uptake, K-uptake and yield of sweet corn (Zea mays saccharata Sturt). IOP Conference Series: Earth and Environmental Science, 393(1), 012021.

Srdić, J., Pajić, Z., Filipović, M., Babić, M., Sečanski, M., Srdić, J., Pajić, Z., Filipović, M., Babić, M., \& Sečanski, M. (2011). Inheritance of ear yield and its components in sweet corn (Zea mays L. saccharata). Genetika, 43(2), 341-348.

Stolz, H., Stolze, M., Hamm, U., Janssen, M., \& Ruto, E. (2011). Consumer attitudes towards organic versus conventional food with specific quality attributes. NJAS-Wageningen Journal of Life Sciences, 58(3-4), 67-72.

Villaver, J. P. (2019). Physiological Efficiency of Sweet Corn (Zea mays L. var. Saccharata) as Influenced by Indigenous Microorganisms (IMO) 7 and Biofertilizers. International Journal of Science and Management Studies (IJSMS), 2(4), 55-66. 
Yan, Z., Liu, P., Li, Y., Ma, L., Alva, A., Dou, Z., Chen, Q., \& Zhang, F. (2013). Phosphorus in China's intensive vegetable production systems: Overfertilization, soil enrichment, and environmental implications. Journal of Environmental Quality, 42(4), 982-989.

Yazdani, M., Bahmanyar, M. A., Pirdashti, H., \& Esmaili, M. A. (2009). Effect of phosphate solubilization microorganisms (PSM) and plant growth promoting rhizobacteria (PGPR) on yield and yield components of corn (Zea mays L.). World Academy of Science, Engineering and Technology, 49, 90-92.

Zander, K., \& Hamm, U. (2010). Consumer preferences for additional ethical attributes of organic food. Food Quality and Preference, 21(5), 495-503.

Zhang, Y., Li, C., Wang, Y., Hu, Y., Christie, P., Zhang, J., \& Li, X. (2016). Maize yield and soil fertility with combined use of compost and inorganic fertilizers on a calcareous soil on the North China Plain. Soil and Tillage Research, 155, 85-94. 